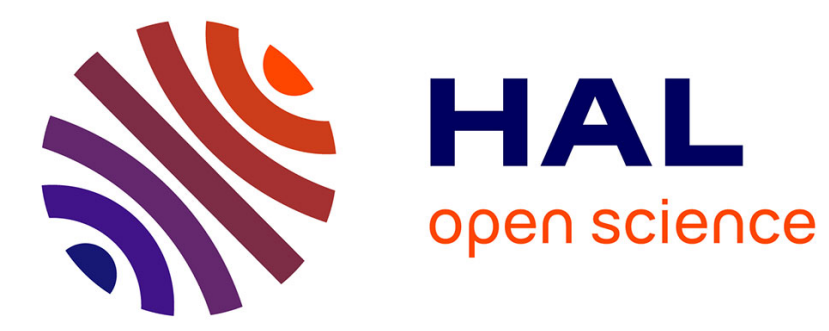

\title{
Heat treatments for sustainable control of soil viruses
}

\author{
Andrea Luvisi, Alessandra Panattoni, Alberto Materazzi
}

\section{To cite this version:}

Andrea Luvisi, Alessandra Panattoni, Alberto Materazzi. Heat treatments for sustainable control of soil viruses. Agronomy for Sustainable Development, 2015, 35 (2), pp.657-666. 10.1007/s13593-0140258-x . hal-01284284

\section{HAL Id: hal-01284284 \\ https://hal.science/hal-01284284}

Submitted on 7 Mar 2016

HAL is a multi-disciplinary open access archive for the deposit and dissemination of scientific research documents, whether they are published or not. The documents may come from teaching and research institutions in France or abroad, or from public or private research centers.
L'archive ouverte pluridisciplinaire HAL, est destinée au dépôt et à la diffusion de documents scientifiques de niveau recherche, publiés ou non, émanant des établissements d'enseignement et de recherche français ou étrangers, des laboratoires publics ou privés. 


\title{
Heat treatments for sustainable control of soil viruses
}

\author{
Andrea Luvisi • Alessandra Panattoni • Alberto Materazzi
}

Accepted: 3 October 2014 / Published online: 4 November 2014

(C) INRA and Springer-Verlag France 2014

\begin{abstract}
Food contamination by toxic pesticides has induced intense research for alternative methods to control pests and diseases. For instance, the phasing out of methyl bromide used for soil disinfection has led to a reconsideration of heat-based methods to control soil-borne pathogens. Techniques such as soil steaming and soil solarization have been applied successfully. However, traditional steaming and solarization are unable to control viruses such as the Tobacco mosaic virus. Thus, methods for sustainable control of virus in soil are not available. Here, we tested the effect of short-duration soil steaming enhanced by the addition of exothermically reacting chemicals - potassium hydroxide or calcium oxide - and soil solarization. These methods were tested against three viruses having different stability: the highly stable Tobacco mosaic virus and the medium stable Potato virus $Y$, and the Cucumber mosaic virus as non-persistent control. Steaming was done in laboratory and open-field conditions after incorporation of exothermically reacting chemicals. Soils were solarized for 20 days using transparent polyethylene, ethylene-vinylacetate and high-effectiveness infrared films. Our results show that steaming with exothermic chemicals decreased the infectivity of the Tobacco mosaic virus below $3.0 \%$. We also found that the Tobacco mosaic virus was not controlled by solarization. The Potato virus $Y$ was totally controlled by steam treatments and by soil solarization with ethylene-vinylacetate or higheffectiveness infrared films. Overall, our findings evidence promising ways to control soil viruses.
\end{abstract}

All authors contributed equally to this work.

A. Luvisi $(\varangle) \cdot$ A. Panattoni $\cdot$ A. Materazzi

Department of Agriculture, Food and Environment, University of

Pisa, Via del Borghetto 80, 56124 Pisa, Italy

e-mail: aluvisi@agr.unipi.it

A. Panattoni

e-mail: alessandra.panattoni@unipi.it

A. Materazzi

e-mail: alberto.materazzi@unipi.it
Keywords Soil disinfection $\cdot$ Solarization $\cdot$ Steaming $\cdot$ Virus

\section{Introduction}

Methyl bromide was phased out in 2005 pursuant to the Montreal Protocol on Substances that Deplete the Ozone Layer, imposing a re-thinking of techniques to control soilborne pathogens (McSorley et al. 2009). The search for alternatives began a decade before the deadline, but it was soon clear that none of the available and registered chemical alternatives has the full spectrum of activity and versatility of methyl bromide as a pre-plant soil fumigant (Duniway 2002). Moreover, all of the chemical alternatives to methyl bromide are subject to continuing review and the risk that registered fumigants will not be available indefinitely for large-scale use in soil is very likely.

In this perspective, it seems appropriate to reconsider physical methods for soil disinfection, even if some common issues (i.e. costs, times of treatments, efficacy) may still cause concerns. Among physical methods, heat treatments, such as steam and solarization, represent traditional approaches to soil-borne pathogen and weed control, thanks to their potentially wide spectrum of action and lack of residues (Katan 2000; Gill and McSorley 2011).

Steam soil disinfestation is now being reconsidered in openfield and greenhouse horticulture for its efficiency, while it ensures low ecological impact (Gay et al. 2010). Short-duration steaming ( $3 \mathrm{~min}$ ) may represent an effective approach for mobile steaming treatment and may reduce costs to control fungal pathogens, nematode pests and weeds (van Loenen et al. 2003). Moreover, the addition of exothermically reacting chemicals to steam able to release energy when reacting with water can improve the effectiveness of short-duration heat treatments (Luvisi et al. 2006, 2008) and it is economically competitive with chemical fumigation (Peruzzi et al. 2012). Tests showed the potential for this approach to control various soil- 
borne pathogens, and it may therefore serve as an alternative to chemical soil disinfestation for horticultural crops. The advantages of the combination of steam and exothermically reacting chemicals for management of soil-borne pathogens were associated to reduced labour and fuel consumption for open-field application in comparison with other physical soil disinfection systems (Peruzzi et al. 2011).

Soil solarization is a milder heat treatment. It has recently been re-evaluated, thanks to the development of novel plastic films able to reduce treatment time and enhance biological effects (Gill et al. 2009). Moreover, new techniques combining soil biofumigation and soil solarization (biosolarization) represent promising sustainable options for plant production (Domínguez et al. 2014; Mauromicale et al. 2010) and add beneficial soil microbes (Camprubí et al. 2007).

Viruses are rarely investigated with regard to heat treatments for soils, but soil-borne inoculum of viruses can be very important in primary infection. Shoots and roots or the remains of both in soil have been considered the principal reservoir of high-stability viruses such as Tobamovirus responsible for Tobacco mosaic virus initial infections (Candemir et al. 2012). Considerable quantities of soil-borne viruses that are excreted into the rhizosphere from infected plants could serve as inoculum (Allen 1981), and transmission presumably occurs when root hairs are damaged in the presence of infected debris or when virus leached from infected soil is disseminated to leaves through splashing or other means. In this context, the stability of the virus particles plays a key role, contributing to its survival in the field and facilitating its dissemination by human actions, which could explain its spread without a biological vector (Saraiva et al. 2006). The elimination of a high-stability virus such as Tobacco mosaic virus was investigated with traditional soil disinfestation methods during the twentieth century but without satisfactory results. Broadbent et al. (1965) reported how virus in undiluted tomato leaf sap was inactivated by steam treatments at $88-82{ }^{\circ} \mathrm{C}$ for 5-20 min, while root tissues need $90-85^{\circ} \mathrm{C}$ for $10-20 \mathrm{~min}$. Most commercial soil fumigants are ineffective in inactivating the virus directly or increase its survival, presumably by killing microorganisms that denature the virus (Broadbent et al. 1965). Moreover, attempts at soil solarization using first-generation films were unable to reduce virus inoculum in soil (Triolo and Materazzi 1992).

Thus, to evaluate the spectrum of activity of enhanced heat treatments such as short-duration soil steaming plus exothermically reacting chemicals or soil solarization with novel plastic films, three viruses having different stability to environmental factors (Luvisi et al. 2012; Mehle and Ravnikar 2012) were chosen: Tobacco mosaic virus as high-stability virus, Potato virus $Y$ as mid-stability virus and Cucumber mosaic virus as low-stability virus, the latter was used as non-persistent control.

\section{Materials and methods}

\subsection{Inoculum preparation}

A collection of virus isolates of Tobacco mosaic virus, Potato virus $Y$ and Cucumber mosaic virus were maintained in tobacco plants (Nicotiana tabacum L. cv. Turkish) under greenhouse conditions $\left(18-24{ }^{\circ} \mathrm{C}\right)$, free from insects. The plants, systematically infected by an isolate of virus type-strain identified by RT-PCR (Luvisi et al. 2011), were used as the inoculum source of viruses. Crude sap was obtained from leaves of infected plants by grinding leaves with $0.03 \mathrm{M}$ phosphate buffer at $\mathrm{pH} 7.2(1: 4 \mathrm{w} / \mathrm{v}, \mathrm{g} / \mathrm{mL})$. The crude sap was uniformly mixed with air-dried soil samples $(5 \mathrm{~g}$ of soil collected from the plots used for open-field tests) in the proportion of 1:5 $(\mathrm{v} / \mathrm{w})$. The resulting mixtures were arranged in nylon screen $(50 \mathrm{mesh})$ bags (about $8 \times 8 \times 2 \mathrm{~cm}$ high). Three bags per treatment were buried in the soil at depths of 20 and $40 \mathrm{~cm}( \pm 1 \mathrm{~cm}) 12 \mathrm{~h}$ before treatments.

Stability in sap of the tested virus strains was evaluated by determining its longevity in vitro and thermal inactivation point using infected tobacco of the collection as the source of virus (Nascimento et al. 2010). The physical properties were determined by inoculation of nine young tobacco plants with each treatment. The thermal inactivation point was estimated using the temperature range 45 to $95^{\circ} \mathrm{C}$ per $10 \mathrm{~min}$, and the longevity in vitro was determined using the periods of 0 , 100, 200 and 300 days for TMV; 0, 30, 33 and 36 days for Potato virus $Y$; and 0, 3, 5 and 7 days for Cucumber mosaic virus. Stability data and other physical characteristics of viruses (size, genome partition, RNA \%, CG \%) were used to evaluate the virus variables with statistical methods (Luvisi et al. 2012).

\subsection{Heat treatments}

\subsubsection{Soil steaming treatments}

To secure information about the effects of the addition of exothermically reacting chemicals to short-duration steaming against viruses, two trials were carried out: a laboratory test using a specially constructed apparatus for soil steaming and an open-field test using a self-propelling soil steaming machine. The soil characteristics for both trials were sandy loam $(62.5 \%$ sand, $21.0 \%$ silt, $16.5 \%$ clay, $1.0 \%$ organic matter, moisture holding capacity $14.8 \%$, pH 7.4, electrical conductivity $188 \mathrm{mS} \mathrm{cm}{ }^{-1}$, exchangeable potassium $63.22 \mathrm{ppm}$, active calcium carbonate $2.35 \%$ ). In each trial, virus samples were buried at $20-$ and $40-\mathrm{cm}$ depth. The treatments performed for each trial were steam and steam with exothermically reacting chemicals: calcium oxide $(\mathrm{CaO})$ or potassium hydroxide $(\mathrm{KOH})$, at $1000 \mathrm{~kg} \mathrm{ha}^{-1}$ or equivalent dose 
for laboratory test. After each treatment, the soil was covered with a $40-\mu \mathrm{m}$-thick black polyethylene film for $24 \mathrm{~h}$. Untreated virus samples were used as control.

For laboratory tests, the apparatus was devised to simulate the thermal effects caused by a mobile steam generator. The specific adopted target for designing the apparatus was the time-temperature profiles obtained by open-field soil steaming (Luvisi et al. 2006). The apparatus consisted of a $100 \times 80 \times 80-\mathrm{cm}$ box containing a steam injection system composed of two pipes as steam dispenser $20 \mathrm{~cm}$ space-out at $40-\mathrm{cm}$ depth. The injection system was $100 \mathrm{~cm}$ wide with 20 holes for steam dispensing. The steam discharge was $500 \mathrm{~kg} \mathrm{~h}^{-1}$ with a pressure of 1.0 MPa. The box was filled with soil, or, for soil steaming treatments with exothermically reacting chemicals, $\mathrm{CaO}$ or $\mathrm{KOH}(0.08 \mathrm{~kg}$, the equivalent of $1000 \mathrm{~kg} \mathrm{ha}^{-1}$ used for open-field treatments) was manually mixed with soil up to $40-\mathrm{cm}$ depth. Virus samples were buried between the two pipes at $20-$ and $40-\mathrm{cm}$ depth. Steam was dispensed for $60 \mathrm{~s}$ by the first pipe and for $60 \mathrm{~s}$ by the second pipe in order to achieve the target time-temperature profiles obtained by mobile steam generator. Each treatment/virus combination was replicated three times.

Open-field soil steaming was carried out in San Piero a Grado (PI), central Italy, in July over a 2-year period. Plots of $1 \mathrm{~m}^{2}$ were prepared, and randomized layouts with three replicates for a treatment/virus combination were used. Soil steaming was carried out using a selfpropelling machine (Peruzzi et al. 2011) able to spread the exothermically reacting chemicals $\left(1000 \mathrm{~kg} \mathrm{ha}^{-1}\right.$ of $\mathrm{CaO}$ or $\mathrm{KOH}$ ) on the soil surface from a hopper, and then, they were incorporated into the soil by means of a rotor blade (Fig. 1). Behind the rotor, a steam injection system was positioned and connected to the steam generator via a feed pipe: this steam dispenser was filled at $40-\mathrm{cm}$ depth by a system for the adjustment of rotor working depth. After the release of steam and exothermically reacting chemicals, a roller and ridgingmulching machine covered the soil with a plastic film. The steam discharge was $600 \mathrm{~kg} \mathrm{~h}^{-1}$, with a pressure of 1.2 MPa. The injection system was $160 \mathrm{~cm}$ wide with 70 holes for steam dispensing. The treatments were carried out with a feeding speed of $60 \mathrm{~m} \mathrm{~h}^{-1}$.

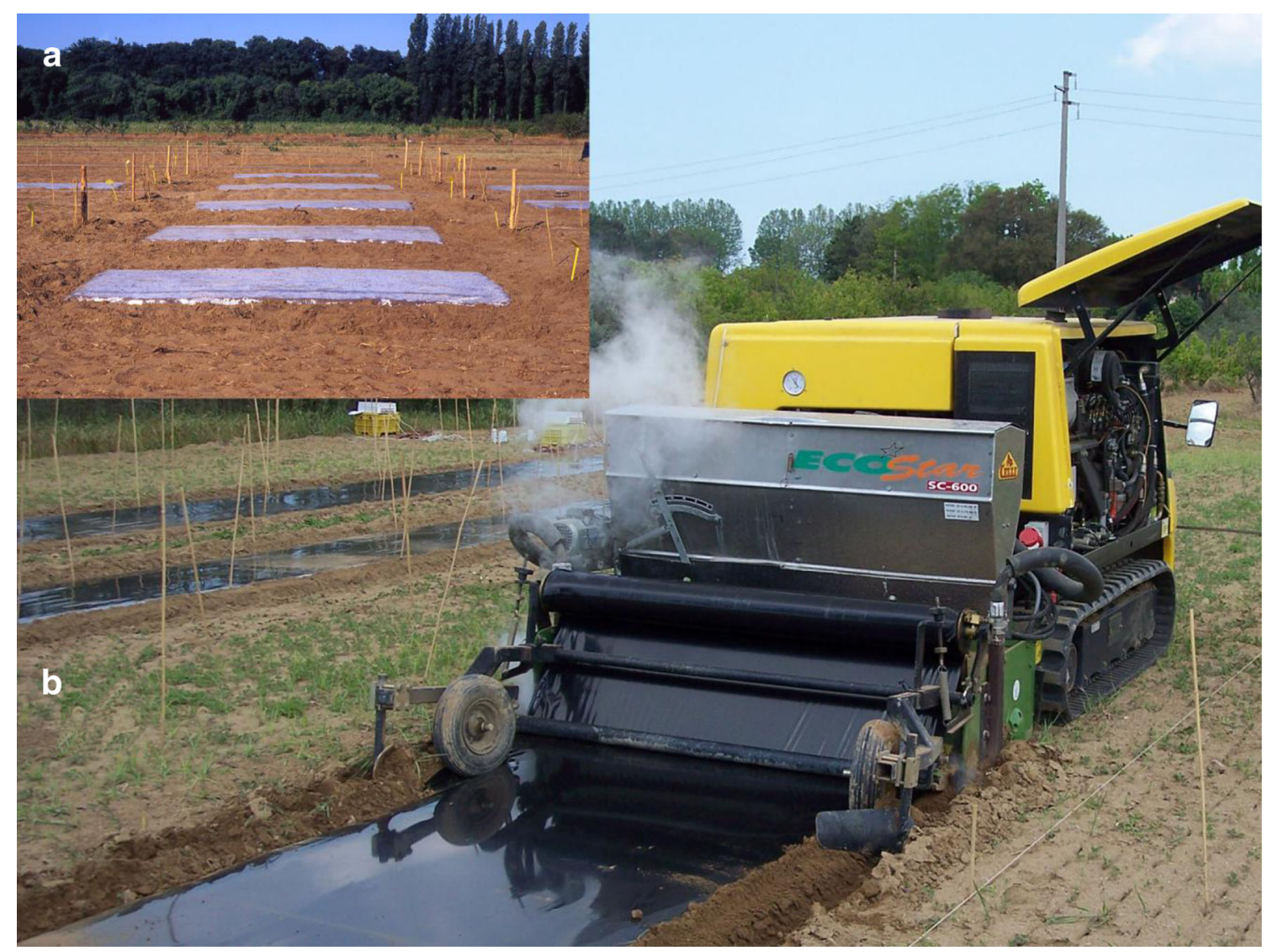

Fig. 1 Soil solarization (a) was carried out using three plastic films: transparent polyethylene film, ethylene-vinylacetate thermic clear film and high-effectiveness infrared film. Soil steaming (b) was carried out using a self-propelling machine able to spread exothermically reacting chemicals (1000 kg ha ${ }^{-1}$ of $\mathrm{CaO}$ or $\mathrm{KOH}$ ) on the soil from a hopper, and then, they were incorporated into the soil by means of a rotor blade 


\subsubsection{Soil solarization treatments}

Soil solarization (Kasirajan and Ngouajio 2012) was carried out in San Piero a Grado (PI), central Italy, in July over a 2-year period using three plastic films: transparent polyethylene film (50- $\mu \mathrm{m}$-thick), ethylene-vinylacetate film (30- $\mu \mathrm{m}$-thick) and high-effectiveness infrared film (30- $\mu \mathrm{m}$-thick). Plots of $1 \mathrm{~m}^{2}$ were prepared, and randomized layouts with three replicates for each treatment/virus combination were used. The soil characteristics were sandy loam $(63.0 \%$ sand, $21.5 \%$ silt, $16.2 \%$ clay, $1.3 \%$ organic matter, moisture holding capacity $15.1 \%$, $\mathrm{pH} 7.4$, electrical conductivity $190 \mathrm{mS} \mathrm{cm}{ }^{-1}$, exchangeable potassium $62.85 \mathrm{ppm}$, active calcium carbonate $2.31 \%$ ). There have not been heavy rainfall during the trials (below $10 \mathrm{~mm}$ during each trial), the mean max temperature was $31{ }^{\circ} \mathrm{C}$, and the mean min temperature was $22^{\circ} \mathrm{C}$. Total visible light emission was $\geq 88,89$ or 91 (test method EN 2155-5) for the polyethylene film, ethylene-vinylacetate film or higheffectiveness infrared film, respectively. Diffused light was $\leq 30,18$ or 20 (test method EN 2155-5) for the polyethylene film, ethylene-vinylacetate film or high-effectiveness infrared film, respectively. Infrared effectiveness was $\geq 30,82$ or 95 (test method EN 13206) for the polyethylene film, ethylenevinylacetate film or high-effectiveness infrared film, respectively. Films covered the soil for 20 days. Full details regarding field preparation are presented elsewhere (Stapleton 2000).

\subsubsection{Soil temperature}

The box and plots were monitored for temperature using a dedicated system made up of PT100 bifilar sensors (PT100420 degree $\mathrm{B}$, in compliance with IEC 751) connected to a data logger (Peruzzi et al. 2012). Sensors, two per box or plot positioned in the central area, were placed vertically along the soil profile until the desired depth $(20$ or $40 \mathrm{~cm})$. The highest, lowest and average soil temperatures after the various treatments were measured and calculated. For soil steaming treatments, the measured temperatures were divided into four classes $\left(T \leq 40{ }^{\circ} \mathrm{C}, 40{ }^{\circ} \mathrm{C}<T \leq 60{ }^{\circ} \mathrm{C}, 60{ }^{\circ} \mathrm{C}<T \leq 80{ }^{\circ} \mathrm{C}, T>\right.$ $\left.80^{\circ} \mathrm{C}(\mathrm{min})\right)$. The length of time each class persisted in the soil was taken into account, along with the highest, average and the final (after $3 \mathrm{~h}$ ) temperature values. The thermal addition parameter $\left(\sum T\right)$ was calculated as the sum of the individual temperatures (measured every minute) for the $180 \mathrm{~min}$ following steam treatment.

\subsection{Virus recovery and infectivity tests}

Purified viruses were utilized to construct a calibration curve for quantitative determinations by means of a dilution series of stocks of purified viruses (Noordam 1973). Virus concentration was estimated spectrophotometrically by using a specific extinction coefficient $\left(E^{0.1 \%}{ }_{1 \mathrm{~cm}}, 260 \mathrm{~nm}\right)$ of 3.1 for Tobacco mosaic virus, 5.0 for Cucumber mosaic virus and 1.21 for Potato virus $Y$ (Brunt et al. 1996). With regard to the inoculum source of virus and its dilution, quantification of virus can be carried out by DAS-ELISA (Candemir et al. 2012; Luvisi et al. 2011; Yang et al. 2012). Three bags per treatment were recovered $24 \mathrm{~h}$ after soil steaming or soil solarization. Each soil sample was separately processed for virus extraction according to the procedure of Cheo (1980) with minor modifications. Soil was extracted with $0.075 \mathrm{M}$ phosphate buffer at $\mathrm{pH} 7.5$ in the proportion of $1: 10(w / v)$. After being thoroughly stirred, the suspension was subjected to $10 \mathrm{~min}$ of ultrasonic vibration (Bransonic 221). This was followed by two cycles of differential centrifugation at $4000 \mathrm{~g}$ for $30 \mathrm{~min}$ and at $15,000 \mathrm{~g}$ with PEG for $15 \mathrm{~min}$. The recovered viruses in the final pellets were suspended in $0.01 \mathrm{M}$ phosphate buffer at $\mathrm{pH} 7.2$ for quantitative assessment and for infectivity tests.

Serological verification of virus was carried out using polyclonal antibodies against Tobacco mosaic virus, Cucumber mosaic virus and Potato virus Y (LOEWE Biochemica $\mathrm{GmbH}$, Germany). Absorbance values (405 nm) were determined with a Titertek Multiskan photometer (Flow Lab., Switzerland). Optical density was correlated to concentration by calibration curve. Virus recovery was expressed as the concentration of virus extracted from buried samples compared to concentration of virus in crude sap of infected plants (\%).

At the end of each trial, the levels of infectivity of viruses from the soil extracts were assessed by mechanical inoculation of leaves of Chenopodium quinoa plants. Each soil extract was used to inoculate ten leaves of $C$. quinoa. Inoculated plants were placed in a climatic chamber at a temperature of $23 \pm 2{ }^{\circ} \mathrm{C}$, light intensity of $200 \mu \mathrm{Em}^{-2} \mathrm{~s}^{-1}$ and photoperiod of $16 \mathrm{~h}$ and monitored for 10 days to evaluate the development of chlorotic lesions. Infectivity recovery was expressed as the number of chlorotic lesions caused by virus extracted from buried samples compared to those caused by crude sap of infected plants (\%).

\subsection{Microbial tests}

Soil samples were collected after treatments at 20-cm depth to evaluate total fungi, Trichoderma spp. and actinomycetes as CFU per gramme of soil, using potato dextrose agar, P190 and water-agar medium, respectively. Community-level physiological profiles of soil microbial communities, using EcoPlates (Biolog Inc., CA, USA) incubation, were carried out by calculating the average well colour development, richness and Shannon-Weaver index (Chen et al. 2013).

\subsection{Statistical analysis}

Virus and infectivity recovery were elaborated using SigmaPlot software (version 11; Systat Software, San Jose, CA, USA). Effectiveness of steam treatments (alone or with 
$\mathrm{CaO}$ or $\mathrm{KOH}$ ) or solarization treatments (three plastic films: polyethylene film, ethylene-vinylacetate film or higheffectiveness infrared film) on virus samples buried at 20 $40-\mathrm{cm}$ depth was compared. The software was used to perform three-way analysis of variance (ANOVA) in a random design and pairwise multiple comparisons on significant effects and interactions using the Holm-Sidak method. Normality and equal variance tests were performed. Data expressed in percent were converted to arcsin values. $P$ lower than 0.05 was considered to be significant. Principal component analysis, a multivariate approach, was performed to evaluate the virus variables.

\section{Results and discussion}

Exothermically reacting chemicals increased the $\sum T, T$ max, $T$ mean and $T$ final achieved after soil steaming in laboratory tests (Table 1). With regard to depth $(20$ or $40 \mathrm{~cm}), \mathrm{CaO}$ caused an increase of 10.0-14.0\% in $\sum T$ and kept the temperature above
$80{ }^{\circ} \mathrm{C}$ for longer $(+33.3-66.7 \%)$ compared to soil steaming. $\mathrm{KOH}$ caused an increase of $6.1-9.3 \%$ in $\sum T$ and kept the temperature above $80^{\circ} \mathrm{C}$ for periods greater than $25.5-54.2 \%$ compared to soil steaming. With regard to depth $(20$ or $40 \mathrm{~cm})$, $\mathrm{CaO}$ caused an increase of 8.2-9.7\% in soil $\mathrm{pH}$ compared to soil steaming, while $\mathrm{KOH}$ caused an increase of $10.0-10.8 \%$. After 20 days, the $\mathrm{pH}$ of soil was normalized, with a final increase of $1.5 \%$ at $20-\mathrm{cm}$ depth and $1.2 \%$ at $40-\mathrm{cm}$ depth after soil steaming with exothermically reacting chemicals. Similar temperature behaviour (within $2.8 \%$ of variance) was recorded in open-field tests. Soil solarization led to different temperature profiles depending on the film applied to soil (Table 1 ). $\sum T$ was increased by 11.0 and $12.6 \%$ by ethylenevinylacetate film and high-effectiveness infrared film compared to polyethylene film, respectively. According to depth (40 or $20 \mathrm{~cm}$ ), both ethylene-vinylacetate film and high-effectiveness infrared film increased maximum soil temperature by $5.2-9.3$ and $5.5-10.1 \%$ compared to polyethylene film, respectively.

To estimate virus concentration, a calibration curve $(r=$ $99 \%$ was constructed in order to correlate optical density with concentration. In laboratory tests, soil steaming was very

Table 1 Soil temperature, $\mathrm{pH}$ and electrical conductivity at two depths $(20$ and $40 \mathrm{~cm})$ in treated soil with steam (alone or with $\mathrm{CaO}$ or $\mathrm{KOH})$ or solarization (three plastic films: polyethylene film, ethylene-vinylacetate film or high-effectiveness infrared film)

\begin{tabular}{|c|c|c|c|c|c|c|}
\hline & Effect $\mathrm{c}$ & teaming treat & & & & \\
\hline & Soil de & & & & & \\
\hline & $20 \mathrm{~cm}$ & & & $40 \mathrm{~cm}$ & & \\
\hline & Steam & Steam $\mathrm{CaO}$ & Steam $\mathrm{KOH}$ & Steam & Steam $\mathrm{CaO}$ & Steam $\mathrm{KOH}$ \\
\hline Temperature & & & & & & \\
\hline$\sum T$ & $7.382 \mathrm{a}$ & $8.131 b$ & $7.832 \mathrm{c}$ & $8.231 \mathrm{a}$ & $9.385 \mathrm{~b}$ & $8.896 \mathrm{c}$ \\
\hline$T \max \left({ }^{\circ} \mathrm{C}\right)$ & $83.2 \mathrm{a}$ & $90.4 \mathrm{~b}$ & $89.2 \mathrm{c}$ & $89.3 \mathrm{a}$ & $93.5 b$ & $91.6 \mathrm{c}$ \\
\hline$T$ mean $\left({ }^{\circ} \mathrm{C}\right)$ & $51.3 \mathrm{a}$ & $54.3 \mathrm{~b}$ & $53.3 \mathrm{~b}$ & $58.3 \mathrm{a}$ & $62.4 \mathrm{~b}$ & $61.5 b$ \\
\hline$T \min \left({ }^{\circ} \mathrm{C}\right)$ & $42.5 \mathrm{a}$ & $43.3 \mathrm{a}$ & $42.5 \mathrm{a}$ & $43.2 \mathrm{a}$ & $43.3 \mathrm{a}$ & $43.4 \mathrm{a}$ \\
\hline Temperature classes & & & & & & \\
\hline$T \leq 40{ }^{\circ} \mathrm{C}(\mathrm{min})$ & - & - & - & - & - & - \\
\hline $40{ }^{\circ} \mathrm{C}<T \leq 60{ }^{\circ} \mathrm{C}(\mathrm{min})$ & $101 \mathrm{a}$ & $86 \mathrm{~b}$ & $90 \mathrm{c}$ & $91 \mathrm{a}$ & $62 \mathrm{~b}$ & $71 \mathrm{c}$ \\
\hline $60^{\circ} \mathrm{C}<T \leq 80^{\circ} \mathrm{C}$ (min) & $58 \mathrm{a}$ & $66 \mathrm{~b}$ & $64 \mathrm{c}$ & $61 \mathrm{a}$ & $71 \mathrm{~b}$ & $67 \mathrm{c}$ \\
\hline$T>80^{\circ} \mathrm{C}$ (min) & $21 \mathrm{a}$ & $28 b$ & $26 \mathrm{c}$ & $28 \mathrm{a}$ & $47 \mathrm{~b}$ & $42 \mathrm{c}$ \\
\hline Soil parameters & & & & & & \\
\hline $\mathrm{pH}$ & $7.41 \mathrm{a}$ & $8.02 \mathrm{~b}$ & $8.15 b$ & $7.40 \mathrm{a}$ & $8.12 \mathrm{~b}$ & $8.20 \mathrm{~b}$ \\
\hline Electrical conductivity $\left(\mathrm{mS} \mathrm{cm}^{-1}\right)$ & $225 \mathrm{a}$ & $238 b$ & $235 b$ & $241 \mathrm{a}$ & $281 \mathrm{~b}$ & $279 b$ \\
\hline & Effect $\mathrm{c}$ & solarization tr & & & & \\
\hline & Soil de & & & & & \\
\hline & $20 \mathrm{~cm}$ & & & $40 \mathrm{~cm}$ & & \\
\hline & PEF & EVA & IRF & PEF & EVA & IRF \\
\hline Temperature & & & & & & \\
\hline$T \max \left({ }^{\circ} \mathrm{C}\right)$ & 44.1 & 48.2 & 48.6 & 24.2 & 25.0 & 25.1 \\
\hline$T$ mean $\left({ }^{\circ} \mathrm{C}\right)$ & 35.3 & 37.2 & 36.7 & 23.2 & 24.1 & 24.0 \\
\hline$T \min \left({ }^{\circ} \mathrm{C}\right)$ & 25.3 & 25.2 & 25.3 & 22.1 & 22.2 & 21.9 \\
\hline
\end{tabular}

Within a soil depth, means followed by the same letter are not significantly different at $P=0.05$ by Duncan's multiple range test

$\sum T$ thermal addition, $P E F$ polyethylene film, $E V A$ ethylene-vinylacetate film, $I R F$ high-effectiveness infrared film 
effective against all viruses (Table 2), achieving no virus or infectivity recovery for Potato virus $Y$ or Cucumber mosaic virus, regardless of depth of inoculum or exothermically reacting chemical addition. Conversely, more than $60 \%$ of inoculated Tobacco mosaic virus was recovered after soil steaming and more than $50 \%$ thanks to exothermically reacting chemical addition. However, Tobacco mosaic virus infectivity was drastically reduced by the short-duration steaming, while exothermically reacting chemicals caused a further significant decrease, setting virus recovery below $3.0 \%$, without significant differences among exothermically reacting chemicals. Open-field treatments achieved the same effects against the three viruses (data not shown). The best results were achieved at $40-\mathrm{cm}$ depth, in proximity to the steam dispenser.

As expected, the low stability of Cucumber mosaic virus was underlined by its elimination after 20 days in untreated control plots; thus, soil disinfection was naturally achieved by short set-aside (Table 2). Potato virus $Y$ was totally controlled by soil solarization with ethylene-vinylacetate film or higheffectiveness infrared films at $20-\mathrm{cm}$ depth. Polyethylene film did not eliminate the infectivity of recovered virus even if it was greatly reduced. Solarization did not cause any effect against Tobacco mosaic virus, with virus and infectivity recovery comparable to untreated plots. Solarization did not cause any effect on viruses at $40-\mathrm{cm}$ depth.
Factorial analysis of variance of virus recovery and infectivity after soil solarization treatments or soil steam treatments is reported in Table 3.

Longevity in vitro was esteemed higher than 300 for Tobacco mosaic virus, 36 for Potato virus $Y$ and 5 for Cucumber mosaic virus, according to literature (Luvisi et al. 2012). Considering the principal component analysis performed on the nine chosen parameters (Fig. 2), the first principal component axis accounted for $81.61 \%$ of the observed variation. It was strongly and positively correlated with steam-exothermically reacting chemicals and solarization with ethylene-vinylacetate film or high-effectiveness infrared film. The second principal component axis (18.39\%) was strongly correlated to genome partition and RNA \% and negatively correlated to size and GC \%. Treatments were not substantially correlated to the second principal component axis. The first principal component axis separated Tobacco mosaic virus from Potato virus $Y$ and Cucumber mosaic virus; the second principal component axis separated Potato virus $Y$ from Cucumber mosaic virus. A strong negative correlation was calculated between longevity in vitro or thermal inactivation point and all soil treatments. As reported by Nascimento et al. (2010), longevity in vitro may represent an important parameter in order to choose or optimize the disinfection methods. Anyway, tests report difference between the longevity in vitro found for some viruses and their survival in
Table 2 Virus recovery (virus recovered after treatment out of total virus inoculum, \%) and infectivity recovery (chlorotic lesions caused by viruses recovered compared to control (untreated virus inoculum), \%) considering three viruses (Tobacco mosaic virus, Potato virus $Y$ and Cucumber mosaic virus) buried at two depths $(20$ and $40 \mathrm{~cm})$ in treated soil with solarization (three plastic films: polyethylene film, ethylene-vinylacetate film or high-effectiveness infrared film) or steam (alone or with $\mathrm{CaO}$ or $\mathrm{KOH})$

\begin{tabular}{|c|c|c|c|c|c|c|c|c|c|c|c|c|c|c|c|c|}
\hline \multirow[b]{4}{*}{ Virus } & \multicolumn{8}{|c|}{ Effect of soil steaming treatment } & \multicolumn{8}{|c|}{ Effect of soil solarization treatments } \\
\hline & \multicolumn{2}{|l|}{ Control } & \multicolumn{2}{|l|}{ Steam } & \multicolumn{2}{|c|}{ Steam- $\mathrm{CaO}$} & \multicolumn{2}{|c|}{ Steam-KOH } & \multicolumn{2}{|c|}{ Control } & \multicolumn{2}{|l|}{ PEF } & \multicolumn{2}{|l|}{ EVA } & \multicolumn{2}{|l|}{ IRF } \\
\hline & \multicolumn{16}{|c|}{ Inoculum depth } \\
\hline & $20 \mathrm{~cm}$ & $40 \mathrm{~cm}$ & $20 \mathrm{~cm}$ & $40 \mathrm{~cm}$ & $20 \mathrm{~cm}$ & $40 \mathrm{~cm}$ & $20 \mathrm{~cm}$ & $40 \mathrm{~cm}$ & $20 \mathrm{~cm}$ & $40 \mathrm{~cm}$ & $20 \mathrm{~cm}$ & $40 \mathrm{~cm}$ & $20 \mathrm{~cm}$ & $40 \mathrm{~cm}$ & $20 \mathrm{~cm}$ & $40 \mathrm{~cm}$ \\
\hline \multicolumn{17}{|l|}{ TMV } \\
\hline Virus recovery & $98.4 \mathrm{a}$ & $97.9 \mathrm{a}$ & $71.4 \mathrm{~b}$ & $62.3 b$ & $64.3 \mathrm{c}$ & $52.6 \mathrm{c}$ & $66.0 \mathrm{c}$ & $54.5 \mathrm{c}$ & $97.4 \mathrm{a}$ & $99.1 \mathrm{a}$ & $98.3 \mathrm{a}$ & $97.4 \mathrm{a}$ & $99.1 \mathrm{a}$ & $98.0 \mathrm{a}$ & $98.9 \mathrm{a}$ & $98.3 \mathrm{a}$ \\
\hline $\begin{array}{l}\text { Infectivity } \\
\text { recovery }\end{array}$ & $98.2 \mathrm{a}$ & $97.8 \mathrm{a}$ & $16.7 \mathrm{~b}$ & $13.6 \mathrm{~b}$ & $2.9 \mathrm{c}$ & $1.2 \mathrm{c}$ & $3.0 \mathrm{c}$ & $1.3 \mathrm{c}$ & $97.2 \mathrm{a}$ & $97.2 \mathrm{a}$ & $96.9 \mathrm{a}$ & $97.0 \mathrm{a}$ & $98.2 \mathrm{a}$ & $97.3 \mathrm{a}$ & $97.3 \mathrm{a}$ & $98.0 \mathrm{a}$ \\
\hline \multicolumn{17}{|l|}{ PVY } \\
\hline Virus recovery & $97.9 \mathrm{a}$ & $98.2 \mathrm{a}$ & $0.0 \mathrm{~b}$ & $0.0 \mathrm{~b}$ & $0.0 \mathrm{~b}$ & $0.0 \mathrm{~b}$ & $0.0 \mathrm{~b}$ & $0.0 \mathrm{~b}$ & $75.2 \mathrm{a}$ & $73.4 \mathrm{a}$ & $33.4 \mathrm{~b}$ & $70.3 \mathrm{a}$ & $24.2 \mathrm{c}$ & $73.4 \mathrm{a}$ & $23.2 \mathrm{c}$ & $75.2 \mathrm{a}$ \\
\hline $\begin{array}{r}\text { Infectivity } \\
\text { recovery }\end{array}$ & $97.3 \mathrm{a}$ & $97.8 \mathrm{a}$ & $0.0 \mathrm{~b}$ & $0.0 \mathrm{~b}$ & $0.0 \mathrm{~b}$ & $0.0 \mathrm{~b}$ & $0.0 \mathrm{~b}$ & $0.0 \mathrm{~b}$ & $64.3 \mathrm{a}$ & $61.3 \mathrm{a}$ & $4.4 \mathrm{~b}$ & $58.2 \mathrm{a}$ & $0.0 \mathrm{c}$ & $60.0 \mathrm{a}$ & $0.0 \mathrm{c}$ & $62.0 \mathrm{a}$ \\
\hline \multicolumn{17}{|l|}{ CMV } \\
\hline Virus recovery & $85.3 \mathrm{a}$ & $86.2 \mathrm{a}$ & $0.0 \mathrm{~b}$ & $0.0 \mathrm{~b}$ & $0.0 \mathrm{~b}$ & $0.0 \mathrm{~b}$ & $0.0 \mathrm{~b}$ & $0.0 \mathrm{~b}$ & $0.0 \mathrm{a}$ & $0.0 \mathrm{a}$ & $0.0 \mathrm{a}$ & $0.0 \mathrm{a}$ & $0.0 \mathrm{a}$ & $0.0 \mathrm{a}$ & $0.0 \mathrm{a}$ & $0.0 \mathrm{a}$ \\
\hline $\begin{array}{l}\text { Infectivity } \\
\text { recovery }\end{array}$ & $76.4 \mathrm{a}$ & $75.4 \mathrm{a}$ & $0.0 \mathrm{~b}$ & $0.0 \mathrm{~b}$ & $0.0 \mathrm{~b}$ & $0.0 \mathrm{~b}$ & $0.0 \mathrm{~b}$ & $0.0 \mathrm{~b}$ & $0.0 \mathrm{a}$ & $0.0 \mathrm{a}$ & $0.0 \mathrm{a}$ & $0.0 \mathrm{a}$ & $0.0 \mathrm{a}$ & $0.0 \mathrm{a}$ & $0.0 \mathrm{a}$ & $0.0 \mathrm{a}$ \\
\hline
\end{tabular}

Within a soil depth, means followed by the same letter are not significantly different at $P=0.05$ by Duncan's multiple range test

TMV Tobacco mosaic virus, PVY Potato virus Y, CMV Cucumber mosaic virus, PEF polyethylene film, EVA ethylene-vinylacetate film, IRF higheffectiveness infrared film 
Table 3 Three-way factorial analysis of variance of virus recovery (virus recovered after treatment out of total virus inoculum, \%) and infectivity recovery (chlorotic lesions caused by viruses recovered compared to untreated virus inoculum, \%) considering three viruses (Tobacco mosaic virus, Potato virus $Y$ and Cucumber mosaic virus) buried at two depths

\begin{tabular}{|c|c|c|c|c|c|}
\hline \multicolumn{3}{|l|}{ Solarization } & \multicolumn{3}{|l|}{ Steam } \\
\hline Source of variation & Virus recovery & Infectivity recovery & Source of variation & Virus recovery & Infectivity recovery \\
\hline Main effect & & & Main effect & & \\
\hline Soil treatment $(\mathrm{A})$ & $<0.001$ & $<0.001$ & Soil treatment $(\mathrm{A})$ & $<0.001$ & $<0.001$ \\
\hline Depth (B) & $<0.001$ & $<0.001$ & Depth (B) & $<0.001$ & $<0.001$ \\
\hline Virus (C) & $<0.001$ & $<0.001$ & Virus (C) & $<0.001$ & $<0.001$ \\
\hline Interactions & & & Interactions & & \\
\hline $\mathrm{A} \times \mathrm{B}$ & $<0.001$ & $<0.001$ & $\mathrm{~A} \times \mathrm{B}$ & $<0.001$ & $<0.001$ \\
\hline $\mathrm{A} \times \mathrm{C}$ & $<0.001$ & $<0.001$ & $\mathrm{~A} \times \mathrm{C}$ & $<0.001$ & $<0.001$ \\
\hline $\mathrm{B} \times \mathrm{C}$ & $<0.001$ & $<0.001$ & $\mathrm{~B} \times \mathrm{C}$ & $<0.001$ & $<0.001$ \\
\hline $\mathrm{A} \times \mathrm{B} \times \mathrm{C}$ & $<0.001$ & $<0.001$ & $\mathrm{~A} \times \mathrm{B} \times \mathrm{C}$ & $<0.001$ & $<0.001$ \\
\hline Comparison for A & & & Comparison for $\mathrm{A}$ & & \\
\hline PEF vs. EVA & $<0.001$ & $<0.001$ & Steam vs. steam $\mathrm{CaO}$ & $<0.001$ & $<0.001$ \\
\hline PEF A vs. IRF & $<0.001$ & $<0.001$ & Steam vs. steam $\mathrm{KOH}$ & $<0.001$ & $<0.001$ \\
\hline EVA vs. IRF & $<0.001$ & $<0.001$ & Steam $\mathrm{CaO}$ vs. steam $\mathrm{KOH}$ & $<0.001$ & $<0.001$ \\
\hline Control vs. PEF & $<0.001$ & $<0.001$ & Control vs. steam & $<0.001$ & $<0.001$ \\
\hline Control vs. EVA & $<0.001$ & $<0.001$ & Control vs. steam $\mathrm{CaO}$ & $<0.001$ & $<0.001$ \\
\hline Control vs. IRF & $<0.001$ & $<0.001$ & Control vs. steam $\mathrm{KOH}$ & $<0.001$ & $<0.001$ \\
\hline Comparison for B & & & Comparison for B & & \\
\hline 20 vs. $40 \mathrm{~cm}$ & $<0.001$ & $<0.001$ & 20 vs. $40 \mathrm{~cm}$ & $<0.001$ & $<0.001$ \\
\hline Comparison for $\mathrm{C}$ & & & Comparison for $\mathrm{C}$ & & \\
\hline TMV vs. CMV & $<0.001$ & $<0.001$ & TMV vs. CMV & $<0.001$ & $<0.001$ \\
\hline TMV vs. PVY & $<0.001$ & $<0.001$ & TMV vs. PVY & $<0.001$ & $<0.001$ \\
\hline CMV vs. PVY & $<0.001$ & $<0.001$ & CMV vs. PVY & NS & NS \\
\hline Comparison for A within TMV & & & Comparison for A within TMV & & \\
\hline PEF vs. EVA & NS & NS & Steam vs. steam $\mathrm{CaO}$ & $<0.001$ & $<0.001$ \\
\hline PEF A vs. IRF & NS & NS & Steam vs. steam $\mathrm{KOH}$ & $<0.001$ & $<0.001$ \\
\hline EVA vs. IRF & NS & NS & Steam $\mathrm{CaO}$ vs. steam $\mathrm{KOH}$ & NS & NS \\
\hline Control vs. PEF & NS & NS & Control vs. steam & $<0.001$ & $<0.001$ \\
\hline Control vs. EVA & NS & NS & Control vs. steam $\mathrm{CaO}$ & $<0.001$ & $<0.001$ \\
\hline Control vs. IRF & NS & NS & Control vs. steam $\mathrm{KOH}$ & $<0.001$ & $<0.001$ \\
\hline Comparison for A within CMV & & & Comparison for A within $\mathrm{CMV}$ & & \\
\hline PEF vs. EVA & NS & NS & Steam vs. steam $\mathrm{CaO}$ & NS & NS \\
\hline PEF A vs. IRF & NS & NS & Steam vs. steam $\mathrm{KOH}$ & NS & NS \\
\hline EVA vs. IRF & NS & NS & Steam $\mathrm{CaO}$ vs. steam $\mathrm{KOH}$ & NS & NS \\
\hline Control vs. PEF & NS & NS & Control vs. steam & NS & NS \\
\hline Control vs. EVA & NS & NS & Control vs. steam $\mathrm{CaO}$ & NS & NS \\
\hline Control vs. IRF & NS & NS & Control vs. steam $\mathrm{KOH}$ & NS & NS \\
\hline Comparison for A within PVY & & & Comparison for A within PVY & & \\
\hline PEF vs. EVA & $<0.001$ & $<0.001$ & Steam vs. steam $\mathrm{CaO}$ & NS & NS \\
\hline PEF A vs. IRF & $<0.001$ & $<0.001$ & Steam vs. steam $\mathrm{KOH}$ & NS & NS \\
\hline EVA vs. IRF & NS & NS & Steam $\mathrm{CaO}$ vs. steam $\mathrm{KOH}$ & NS & NS \\
\hline Control vs. PEF & $<0.001$ & $<0.001$ & Control vs. steam & $<0.001$ & $<0.001$ \\
\hline Control vs. EVA & $<0.001$ & $<0.001$ & Control vs. steam $\mathrm{CaO}$ & $<0.001$ & $<0.001$ \\
\hline Control vs. IRF & $<0.001$ & $<0.001$ & Control vs. steam $\mathrm{KOH}$ & $<0.001$ & $<0.001$ \\
\hline
\end{tabular}

Pairwise multiple comparison analysis with Holm-Sidak test is reported. Numbers tabulated are levels of statistical significance

NS not significant, TMV Tobacco mosaic virus, PVY Potato virus Y, CMV Cucumber mosaic virus, PEF polyethylene film, EVA ethylene-vinylacetate film, IRF high-effectiveness infrared film
(20 and $40 \mathrm{~cm}$ ) in treated soil with solarization (three plastic films: polyethylene film, ethylene-vinylacetate film or high-effectiveness infrared film) or steam (alone or with $\mathrm{CaO}$ or $\mathrm{KOH}$ ) compared to control (untreated virus inoculum) 
infected tissue due to the environment in which the virus particles were maintained. Our findings are in agreement with those obtained against Papaya lethal yellowing virus (Nascimento et al. 2010): high longevity in vitro (60 days) did not prevent heat treatment activity that demonstrated to be an efficient agricultural practice for virus inactivation. With regard to relevance of thermal inactivation point in virus elimination, our results are in agreement with those reported by van Loenen et al. (2003): steaming at 50 or $60^{\circ} \mathrm{C}$ for $3 \mathrm{~min}$, followed by an 8 -min resting period in the steamed soil, resulted in a complete kill of weeds, fungal pathogens and nematodes. In our tests, temperature achieved by steam or solarization at 20-cm depth is able to control efficiently a midstability virus such as Potato virus Y. Even if Tobacco mosaic virus is highly resistant to thermal inactivation, the use of exothermically reacting chemicals combined with steam could lead to higher treatment temperature and increased soil heat persistence, thus producing an effect known as "thermal flash" (Peruzzi et al. 2011), able to overcome the difficulty of controlling Tobacco mosaic virus with steam only, in particular adopting a mobile steam generator with a short treatment exposure time. Moreover, the exothermically reacting chemicals raise the soil $\mathrm{pH}$ which may affect virus stability (Kegel and van der Schoot 2006). Various aggregation states of the viral coat protein subunits are stable as a function of the ionic strength and $\mathrm{pH}$. Alkali caused the protein subunits to be stripped from Tobacco mosaic virus RNA beginning at the $5^{\prime}$ end of the RNA, the concave end of the virus rod. Moreover, factors influencing the rate of virus decline in soil, such as temperature, moisture, $\mathrm{pH}$ or presence of antibiotics, have been reported (Cheo 1980), and it has been suggested that microbial activity may contribute to the instability of Tobacco mosaic virus in soil.

\section{Biplot (First and Second principal component axis: 100,00\%)}

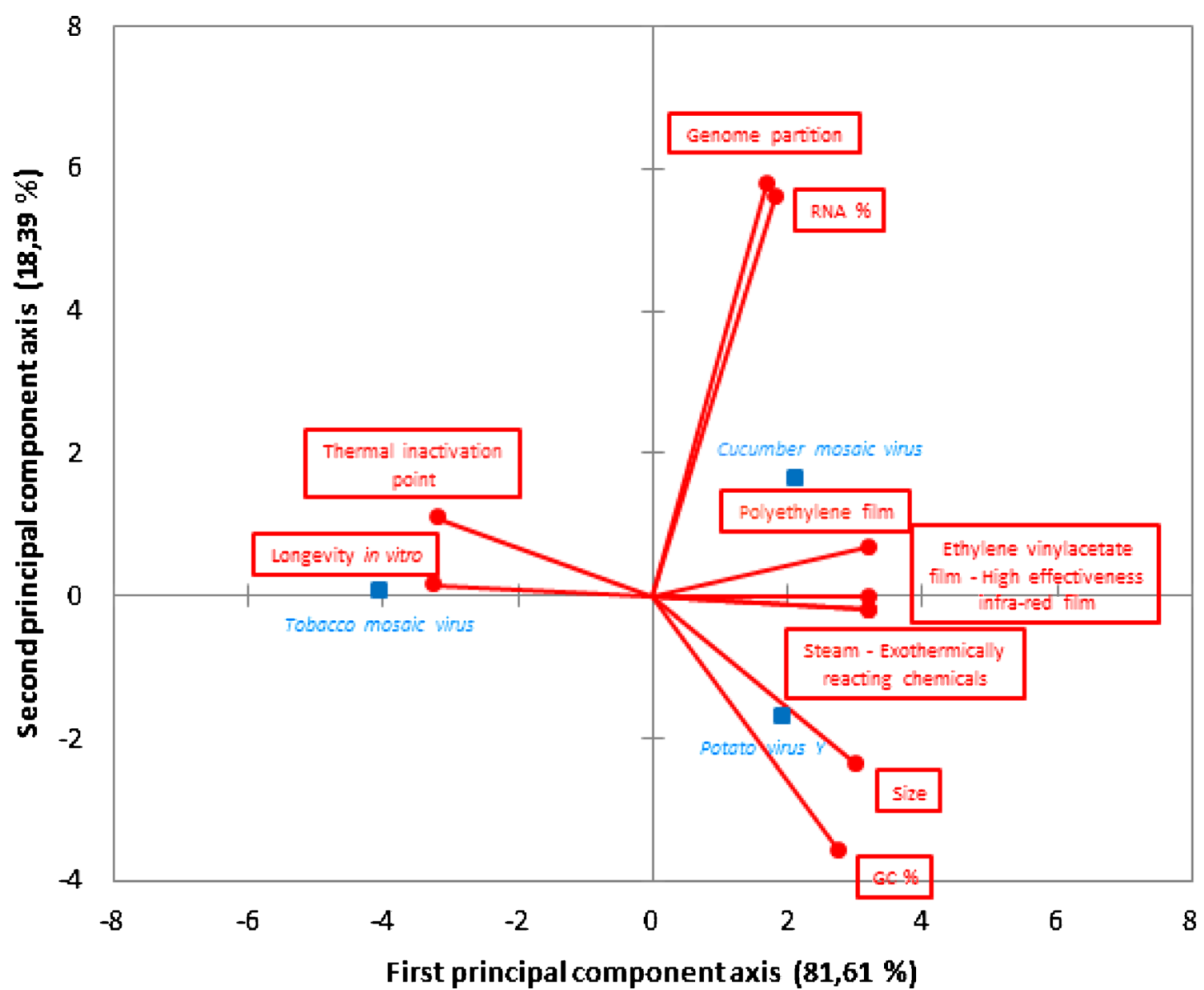

Fig. 2 Biplot of principal component analysis performed to evaluate the virus variables. The first principal component axis separated Tobacco mosaic virus from Potato virus Y and Cucumber mosaic virus, and it was strongly and positively correlated with steam-exothermically reacting chemicals and solarization with ethylene-vinylacetate film or high- effectiveness infrared film. The second principal component axis separated Potato virus $Y$ from Cucumber mosaic virus. A strong negative correlation was calculated between longevity in vitro or thermal inactivation point and all soil treatments 
None of the treatments induced biological vacuum with regard to the investigated microbial community. Soil solarization did not significantly alter total fungi and actinomycetes, while steam treatments led to a reduction in total fungi $(-18.3 \%)$ without detrimental effects caused by exothermically reacting chemicals. The community of Trichoderma spp. was slightly increased with solarization by polyethylene film $(+6.7 \%)$, ethylene-vinylacetate film $(+8.2 \%)$ and higheffectiveness infrared film $(+11.4 \%)$. Short-duration steaming also increased Trichoderma spp. $(+4.2 \%)$ as did $\mathrm{CaO}(+$ $6.3 \%)$ and $\mathrm{KOH}(+5.7 \%)$. Cumulative carbon metabolic activity was the integration of average well colour development over incubation time, relatively indicating the total carbon utilized by soil microbial communities. The soil microbial community of soils treated with solarization exhibited a slight reduction $(9.3 \%)$ of cumulative carbon metabolic activity compared to control, while a significant reduction was calculated for steam (33.3\%), steam plus $\mathrm{CaO}(38.9 \%)$ and steam plus $\mathrm{KOH}(37.3 \%)$. This implies the soil microbial community established after solarization was capable of consuming carbon substrates at nearly the same efficiency as untreated soils unlike to steam and exothermically reacting chemicals. Carbon source utilization richness expressed the number of usable substrates by a soil microbial community and reflected the diversity of microbial metabolism. This measurement was not significantly affected by solarization, steam or steam plus exothermically reacting chemicals. Shannon's index of carbon source utilization was not influenced by heat treatments either, suggesting no effect on functional diversity. With regard to microbial tests, our findings following steam treatments are in agreement with those reported by Gelsomino et al. (2011) in which soil steaming reduced the microbial biomass while the genetic structure of soil bacterial and actinobacterial communities was largely unresponsive to the treatments.

\section{Conclusion}

Up to now, steaming and solarization methods had not yet been valuated considering non-living pathogens such as viruses while one of the most resistant representative - the Tobacco mosaic virus - was known to be almost uncontrollable by traditional solarization or steaming treatments. Our results show that the mid-stability virus Potato virus $Y$ was totally controlled by short-duration steaming charged with exothermically reacting chemicals and the residual infectivity of the high-stability Tobacco mosaic virus was found to be very lower in the treated soil compared to control. Thus, results from this study demonstrate that improved steaming methods, based on high-temperature and short-duration application, tested here seem effective against the most resistant soil-borne virus. Potato virus $Y$ was totally controlled by soil solarization with ethylene-vinylacetate or high-effectiveness infrared films, while polyethylene film did not eliminate the infectivity of recovered virus even if it was greatly reduced. Conversely, Tobacco mosaic virus was unaffected by solarization treatments regardless of films.

Study of a model system such as Tobacco mosaic virus makes it possible to evaluate mobile steam treatments as a valuable method to control important viruses that can infect soils. Moreover, considering the results obtained against various pathogens, this method can be considered a promising approach to address pathological problems that may occur particularly in monoculture practices. On the other hand, even if improved plastic films for solarization are useless to control high-stability viruses, they may represent a very effective tool against mid-stability viruses. Moreover, techniques able to preserve the natural soil biota could be useful for controlling even high-stability viruses, not only in terms of inactivating the virus but also by conserving antiviral biological factors.

\section{References}

Allen WR (1981) Dissemination of tobacco mosaic virus from soil to plant leaves under glasshouse conditions. Can J Plant Pathol 3:163-168

Broadbent L, Read WH, Last FT (1965) The epidemiology of tomato mosaic. X. Persistence of TMV-infected debris in soil and the effect of soil partial sterilization. Ann Appl Biol 55:471-483. doi:10.1111/ j.1744-7348.1965.tb07960.x

Brunt AA, Crabtree K, Dallwitz MJ, Gibbs AJ, Watson L, Zurcher EJ (1996) Plant viruses online: descriptions and lists from the VIDE database. http://pvo.bio-mirror.cn/refs.htm Accessed 07.04.2014

Camprubí A, Estaún V, El Bakali MA, Garcia-Figueres F, Calvet C (2007) Alternative strawberry production using solarization, metham sodium and beneficial soil microbes as plant protection methods. Agron Sustain Dev 27:179-184. doi:10.1051/ agro:2007053

Candemir F, Kutluk-Yilmaz ND, Gülser C (2012) The effect of tobacco waste application on Tobacco mosaic virus (TMV) concentration in the soil. Žemdirbyste 99:99-104

Chen F, Zheng H, Zhang K, Ouyang Z, Wu Y, Shi Q, Li H (2013) Nonlinear impacts of Eucalyptus plantation stand age on soil microbial metabolic diversity. J Soil Sediment 13:887-894. doi:10.1007/ s11368-013-0669-3

Cheo PC (1980) The priming effect on rate of tobacco mosaic virus degradation in soil columns. Soil Sci Soc Am J 44:883-884. doi: 10.2136/sssaj1980.03615995004400040046x

Domínguez P, Miranda L, Soria C, de los Santos B, Chamorro M, Romero F, Daugovish O, López-Aranda JM, Medina JJ (2014) Soil biosolarization for sustainable strawberry production. Agron Sustain Dev. doi:10.1007/s13593-014-0211-z

Duniway JM (2002) Status of chemical alternatives to methyl bromide for pre-plant fumigation of soil. Phytopathology 92:1337-1343. doi:10. 1094/PHYTO.2002.92.12.1337

Gay P, Piccarolo P, Ricauda Aimonino D, Tortia C (2010) A high efficiency steam soil disinfestation system, part I: physical background and steam supply optimization. Biosyst Eng 107:74-85. doi: 10.1016/j.biosystemseng.2010.07.003

Gelsomino A, Petrovičová B, Zaffina F, Peruzzi A (2011) Chemical and microbial properties in a greenhouse loamy soil after steam 
disinfestation alone or combined with $\mathrm{CaO}$ addition. Soil Biol Biochem 42:1091-1100. doi:10.1016/j.soilbio.2010.03.006

Gill HK, McSorley R (2011) Effect of different inorganic/synthetic mulches on weed suppression during soil solarization. Proc Fla State Hortic 124:310-313

Gill HK, McSorley R, Treadwell DD (2009) Comparative performance of different plastic films for soil solarization and weed suppression. HortTechnology 19:769-774

Kasirajan S, Ngouajio M (2012) Polyethylene and biodegradable mulches for agricultural applications: a review. Agron Sustain Dev 32:501-529. doi:10.1007/s13593-011-0068-3

Katan J (2000) Soil and substrate disinfestation as influenced by new technologies and constraints. Acta Hortic 532:29-35

Kegel WK, van der Schoot P (2006) Physical regulation of the selfassembly of Tobacco mosaic virus coat protein. Biophys J 91: 1501-1512. doi:10.1529/biophysj.105.072603

Luvisi A, Materazzi A, Triolo E (2006) Steam and exothermic reactions as alternative techniques to control soil-borne diseases in basil. Agron Sustain Dev 26:201-207. doi:10.1051/agro:2006016

Luvisi A, Materazzi A, Triolo E (2008) Control of soil-borne diseases in tomato by use of steam and exothermic reaction. Adv Hortic Sci 22: 174-181. doi:10.1400/96419

Luvisi A, Panattoni A, Triolo E (2011) Thiopurine prodrugs for plant chemotherapy purposes. J Phytopathol 159:390-392. doi:10.1111/j. 1439-0434.2010.01779.x

Luvisi A, Panattoni A, Triolo E (2012) Eradication trials of tobacco mosaic virus using chemical drugs. Acta Virol 56:155-158. doi: 10.4149/av_2012_02_159

Mauromicale G, Lo Monaco A, Longo AMG (2010) Improved efficiency of soil solarization for growth and yield of greenhouse tomatoes. Agron Sustain Dev 30:753-761. doi:10.1051/agro/2010015

McSorley R, Wang KH, Rosskopf EN, Kokalis-Burelle N, HansPetersen HN, Gill HK, Krueger R (2009) Nonfumigant alternatives to methyl bromide for management of nematodes, soil-borne diseases, and weeds in production of snapdragon (Antirrhinum majus). Int J Pest Manag 55:265-273. doi:10.1080/09670870902878400
Mehle N, Ravnikar M (2012) Plant viruses in aqueous environmentsurvival, water mediated transmission and detection. Water Res 46: 4902-4917. doi:10.1016/j.watres.2012.07.027

Nascimento AKQ, Lima JAA, Nascimento ALL, Beserra EA, Purcifull DE (2010) Biological, physical, and molecular properties of a papaya lethal yellowing virus isolate. Plant Dis 94:1206-1212. doi:10. 1094/PDIS-11-09-0733

Noordam D (1973) Identification of plant viruses. Centre for Agricultural Publishing and Documentation, Wageningen

Peruzzi A, Raffaelli M, Ginanni M, Fontanelli M, Frasconi C (2011) An innovative self-propelled machine for soil disinfection using steam and chemicals in an exothermic reaction. Biosyst Eng 110:434-442. doi:10.1016/j.biosystemseng.2011. 09.008

Peruzzi A, Raffaelli M, Frasconi C, Fontanelli M, Barberi P (2012) Influence of an injection system on the effect of activated soil steaming on Brassica juncea and the natural weed seedbank. Weed Res 52:140-152. doi:10.1111/j.1365-3180.2011.00901.x

Saraiva ACM, Paiva WO, Rabelo Filho FAC, Lima JAA (2006) Transmissão por mãos contaminada e ausência de transmissão embrionária do vírus do amarelo letal do mamoeiro. Fitopatol Bras 31:79-83. doi:10.1590/S0100-41582006000100014

Stapleton JJ (2000) Soil solarization in various agricultural production systems. Crop Prot 19:837-841. doi:10.1016/S0261-2194(00) 00111-3

Triolo E, Materazzi A (1992) Rate of tobacco mosaic virus degradation in solarized soil. Riv Patol Veg 2:23-32

van Loenen MCA, Turbett Y, Mullins CE, Feilden NEH, Wilson MJ, Leifert C, Seel WE (2003) Low temperature-short duration steaming of soil kills soil-borne pathogens, nematode pests and weeds. Eur J Plant Pathol 109:993-1002. doi:10.1023/B:EJPP. 0000003830.49949 .34

Yang JG, Wang FL, Chen DX, Shen LL, Qian YM, Liang ZY, Zhou WC, Yan TH (2012) Development of a one-step immunocapture realtime RT-PCR assay for detection of Tobacco mosaic virus in soil. Sensors 12:16685-16694. doi:10.3390/s121216685 